\title{
Plant Diversity in Sacred Groves of Dapoli: A Comparative Study of Four Life Forms
}

\author{
S.G. Gawade*, V.K. Patil, Y.B. Patil, S.M. Sangare, V.D. Maihske, \\ A.D. Rane and S.S. Narkhede \\ College of Forestry, Dapoli, India \\ *Corresponding author
}

\begin{tabular}{|c|c|}
\hline & A B S T R A C T \\
\hline & \multirow{6}{*}{$\begin{array}{l}\text { The biodiversity-rich sacred groves are of immense ecological significance. They also play } \\
\text { an important role in the conservation of flora and fauna. Besides, several rare and } \\
\text { threatened species are found only in sacred groves, which are, perhaps, the last refuge for } \\
\text { these vulnerable species. In Dapoli Taluka sacred groves have immense potential as } \\
\text { ecosystem service providing habitats. There have been gaps in their documentation. So a } \\
\text { comparative study four life forms was initiated in } 11 \text { sacred grove of Dapoli Taluka. For } \\
\text { the present investigation, } 11 \text { Sacred groves were selected on the basis of size class viz. } 0-5 \text {, } \\
5-10 \text {, and } 10<\text { (Ha). Field surveys and mapping were conducted in selected sacred groves } \\
\text { during October } 2016 \text { to January } 2017 \text { for gathering information on the status, extent, floral } \\
\text { elements etc. A total of } 171 \text { species representing } 145 \text { genera and } 66 \text { families were recorded } \\
\text { in the } 11 \text { sacred groves and associated outside plots. The maximum were trees ( } 92) \\
\text { followed by shrubs (33), herbs }(27) \text {, and climbers }(18) \text { and one orchid species. Among the } \\
\text { families, Fabaceae was most dominant comprising } 12 \text { species and } 10 \text { genera, followed by } \\
\text { Acanthaceae representing } 10 \text { species and } 8 \text { genera. In present study we recorded total } 10 \\
\text { rare and threatened plants and } 29 \text { endemic plants from the } 11 \text { sacred groves of Dapoli } \\
\text { taluka. }\end{array}$} \\
\hline & \\
\hline & \\
\hline Article Info & \\
\hline & \\
\hline & \\
\hline
\end{tabular}

\section{Introduction}

Sacred groves are outstanding and excellent examples of the collective attitudes and beliefs of a rural society. They are the aesthetic symbols of the interaction of man with nature, a rich blend of natural and cultural values. These are believed to be the sites where the ancestors and forefathers lived and the abode of natural spirits or deities. Isolation of such forests has resulted in the conservation of many rare, endangered and endemic species. Their plant wealth and conservation potential were impressive enough to acknowledge them as mini biosphere reserves (Gadgil and Vartak, 1975). The forests associated with these sacred groves are typically different in their vegetation structure and species composition (Chandrashekhar and Shankar 1998).

Biodiversity keeps the ecological processes in a balanced state, which is necessary for human survival. Therefore, the biodiversity-rich sacred groves are of immense ecological significance. They also play an important role 
in the conservation of flora and fauna. Besides, several rare and threatened species are found only in sacred groves, which are, perhaps, the last refuge for these vulnerable species. The importance of sacred groves in the conservation of biological diversity has been well recognized. Vartak (1976) found a grove in the Koloba district of Maharashtra harboring a solitary specimen of the liana Entadaphaseoloides.

Sacred groves are the good source of a variety of medicinal plants, fruits, fodder, fuel wood, spices, etc. Some interesting ethno-botanical studies were conducted by Gadgiland Vartak(1976) in the sacred groves of Maharashtra. Despite their small size, they are important sources of ecosystem services including biodiversity conservation (Ray and Ramachandra 2010).

But in recent times the traditional values appear to be on the gradual decline due to the advent of modernization and various developmental activities. Various anthropogenic activities have altered the structure and function of different ecosystems all over the world. One of the most conspicuous effects of ecosystem perturbation has been the depletion of biodiversity. Disappearance of species due to habitat alteration, overexploitation, pollution, global climate change and invasion of exotic species is so fast that many valuable taxa may vanish even before they are identified and their scientific value is discovered.

In Dapoli taluka sacred groves have immense potential as ecosystem service providing habitats. There have been gaps in their documentation. It is also necessary to bring them in a geographic perspective wherein their information could be useful in taking landscape level decisions. They also need to be conserved and conservation cannot be targeted at abstract entities. They need to be identified, located and mapped. An effort has been made towards this by Patil (2016). However, it needs to be taken further by associating attributes of sacred groves to the mapped land parcels. These attributes could be used as conservation parameters both in ethical and utilitarian approaches.

Therefore, there is an urgent need to study the structure and functions of sacred groves before initiating the conservation strategies to protect them.

\section{Materials and Methods}

This study was carried out in Dapoli Taluka $\left(17^{\circ} 34^{\prime}\right.$ to $17^{\circ} 56^{\prime} ; 73^{\circ} 03^{\prime}$ to $\left.73^{\circ} 20^{\prime}\right)$ of Ratnagiri district. Total geographical area of Dapoli is $846 \mathrm{~km}^{2}$. The landscape of Dapoli is dominated by forests, plateaus, agricultural patches and fruit orchards.

In Dapoli tehsil 110 sacred groves are present as per the records of the revenue department (Patil 2016). They range in size from 0.05 to 40 ha. They are known as Dev-rahati meaning the abode of the deity. For the present investigation, 11 Sacred groves were selected on the basis of size class viz. $0-5,5-10$, and $10<(\mathrm{Ha})$. Field surveys and mapping were conducted in selected sacred groves during October 2016 to January 2017 for gathering information on the status, extent, floral elements etc.

We marked plots in the sacred groves so as to cover core, buffer edge area of each sacred grove. One additional plot was marked in the nearby forest area (hereinafter referred to as vicinity plots). Each plot was sampled using quadrats of different dimensions for different life forms. For trees it was $10 \mathrm{~m} \times 10 \mathrm{~m}$, for shrubs it was $5 \mathrm{~m} \times 5 \mathrm{~m}$, for herbs and climbers it was $1 \mathrm{~m} \times 1 \mathrm{~m}$. These quadrats were nested as within each other. 


\section{Data analysis}

The software program Estimates (Colwell 1997) was used to estimate species richness and associated parameters. Species accumulation curves were generated after 100 randomizations. The non-parametric estimator Jackknife-1 was used as a robust estimator of species richness in each sacred grove (Heltshe and Forrester 1983) and for the pooled data. Jackknife-1gives an estimate of absolute number of species in an assemblage based on number of rare species (species that occur only in one sample; (Magurran 2004). But values of other estimators are also presented in the results and compared for their efficacy and for calculating the completeness of surveys percentage. Completeness of surveys is the number of species discovered in the surveys as a proportion of actual number of species as estimated by the non-parametric estimators. This programme also gave values of diversity indices namely Shannon index and Simpson index.

Program Nestedness (Ulrich, 2006) was used to quantify nestedness of species by site matrix. The program provides nestedness scores in form of 'temperature- $T$ ', the values of which range between0 (perfect order) and 100 (perfect disorder). The significance of the observed temperature was judged from the 95\% CI after 100 randomizations.

The beta diversity using Whittaker's $\beta$ and inverse of Jaccard's index of similarity were calculated as measures of species turnover because of their advantages over other indices was calculated (Wilson and Shmida, 1984).

Species-area relationship was explored using scatter plots and modeling curves in the software PAST. The parameters of power function were estimated for the observed curves. Similarly, logistic regression was fitted to the data to test asymptotic nature of the species-area relationship.

\section{Results and Discussion}

\section{Flora of sacred grove}

Present study aimed at recording maximum number of plant species in the sacred groves and their vicinity through systematic sampling and ad lib recording. In this way, a total of 171 species representing 145 genera and 66 families were recorded in the 11 sacred groves and associated outside plots. The flora recorded exclusively in sacred groves included 127 species, whereas only nine species were recorded exclusively in the vicinity plots. Thirty five species could be recorded in both the areas. The species not recorded in sacred groves included Abrusprecatorius, Anacardium occidentale, Lantana camara, Morinda tinctoria, Semecarpusanacardium, Senna tora, Tectonagrandis, Terminalia chebula, and Woodfordia fruticosa. Some of these species may be present in sacred groves but in very rare numbers. Hence, they were not recorded in sampling effort.

The maximum were trees (92) followed by shrubs (33), herbs (27), climbers (18) and one orchid species (Fig. 1). Among the families, Fabaceae was most dominant comprising 12 species and 10 genera, followed by Acanthaceae representing 10 species and 8 genera.

\section{Species richness}

A total of 65 species of trees, 25 species of shrubs, 9 species of herbs and 12 species of climbers were recorded in the 43 plots laid in 11 sacred groves and 11 plots in the vicinity of scared groves. Out of these, 60 species of trees, 22 species of shrubs, 9 species of herbs and 11 species of climbers were recorded exclusively in sacred groves and 19 species of trees, 13 species of shrubs, 3 species of herb and 6 species of climbers were recorded exclusively in the vicinity plots. For the 
purpose of statistical treatment, only this data of observed species richness is used henceforth.

The species are grouped into different life forms as per the sampling strategy. Maximum number of tree species was recorded in Sadavali followed by Dhankoli, Douli and Kudavale. In case of shrubs, maximum number of species were recorded in Sadavali and Douli followed by Sakhloli and Shivnari. It can be seen that the number of individuals and species recorded for herbs and climbers were relatively very less. It is because most of the ephemeral herbs and climbers could not be recorded in the designated survey season. Therefore, although interpretations based on herbs and climber's data are presented here, they may not carry the robustness. The study carried by the Page et al., (2009) in fragmented scared grove of western Ghat also reported 122 species of trees, 29 species of lianas, 60 spices of shrub and 66 epiphtes in 11 fragmented sacred grove.

\section{Estimated species richness}

Estimates gave values of estimated species richness using several estimators. However, the Jacknife1 is the most reliable estimator (Patil 2016).

Results indicate that estimated species richness of trees was considerably higher than observed species richness in all sacred groves. Whereas for other life forms it was not so different. Only in case of Douli and Dhankoli, the estimated species richness of shrubs was also considerably higher than observed species richness (Fig. 2 and 3).

It was observed that most of the vicinity plots had less number of observed species richness across all sacred groves and across all life forms. Similarly, it was found that estimate Jacknife1 species richness values were significantly greater in case of larger sacred groves and particularly in case of trees and shrubs.

\section{Completeness of survey}

As can be seen from above results, the sampling effort has yielded a lesser number of species than that could be recorded using sampling plus other methods. Thus, sampling usually presents a problem of incomplete survey of species diversity.

It could be seen that minimum completeness recorded in herb (47-97\%) whereas the other three life forms recorded relatively high per cent completeness (56-91\%).

It is very interesting to note that despite recording 60 species of trees in sacred groves, the maximum completeness is 72 per cent. On the other hand, in the vicinity plots, only 19 tree species were recorded yet there was completeness to the tune of 92 per cent. This clearly indicates that, despite a greater sampling effort $(n=43)$ failed to record all maximum possible tree species. And this is a clear proof that sacred groves support a rich flora compared with adjacent forest patches.

It can be seen that in general completeness is higher in smaller sacred groves because the sampling effort was almost adequate to record the maximum possible species in smaller areas. However, the smaller values of completeness in case of larger sacred groves provide guideline to increase the sampling effort so as to make it adequate.

\section{Species accumulation curve}

Species accumulation curves for different lifeforms for pooled data of sacred groves are shown in Figure 4. These curves buttress the results of completeness analysis. It can be clearly seen that the curve for trees is not 
showing any sign of reaching an asymptote even after 43 samples. On the other hand, other life forms have stabilized after a few samples. However, it must be noted that the herbs data in the present study is not sufficient as the season in which survey was conducted had very little presence of ephemeral herbaceous plant species.

\section{Species-area relationship}

Species-area relationship investigation of the life forms across the sacred groves under study was done. The only significant and positive correlation was found in case of trees where species richness increased with area of the sacred grove patch. For other life forms, there was no conclusive relationship. Even the logistic regressions indicate the only asymptotic relationship in case of trees (Fig. 5). For shrubs, it comes closer to an asymptotic relationship, but the initial part of the curve does not fit. Given the high number of trees recorded in this study compared to shrubs, climbers and herbs, this kind of result was expected. A positive species-area relationship, as indicated that species richness was a function of patch area, highlighting once again the importance of species richness in fragmented habitat. isolation plays an important role in colonization process and is one of the important predictors of the species diversity (Page et al., 2009)

\section{Diversity indices}

The Shannon index $\left(\mathrm{H}^{\prime}\right)$ that is considered true indicator of diversity of an assemblage and the Simpson's index (D) which is an indicator of dominance within the community were also worked out for all sacred groves based on tree and shrub assemblages.

Dhankoli sacred groves possessed the most diverse tree assemblage as illustrated by values of both $\mathrm{H}^{\prime}$ and $\mathrm{D}$. On the other hand,
Douli sacred grove possessed the most diverse shrub assemblage. Vanzloli sacred grove where only one shrub species was recorded showed the extreme values of both the indices clearly indicating the academic fact that there was least diversity and highest dominance of a single species (Fig. 6 and 7).

\section{Rank abundance}

Comparison of trees is shown for three size categories, In small size sacred groves Memecylon umbellatum species was most dominant, followed by Nathapodytes nimmoniana, But in medium size class Terminalia bellerica most abundant species. Mammea suriga was second most abundant species in medium size class. In small size classIxora brachiata species was dominant and second was Saraca asoca.

For shrubs Carrisa congesta was most dominant species in small size class and also second-most dominant species in medium size class of sacred groves. Leea indica was most dominant species in medium size class and also second-most in large size class of sacred groves. Justicia adathoda was most dominant in large size class.

Similarly, Eranthemum roseum was most dominant herb in all size class of 11 sacred groves of Dapoli, and also Curcuma pseudomontana was second-most dominant species was found. In case of climber species Jasminun malabericum was most dominant species followed by Cyclea pelteta in small size class.

But most dominant in medium size class Ipomoea campanulata was second-most dominant in medium and large size class and also Dalbergia horrida was most dominant in large size class. 


\section{Spatial turnover}

Spatial turnover is a measure of beta diversity. Spatial turnover at species level was assessed by calculating the Whittaker's $B$ index. The index gives an idea about compositional dissimilarity between two sets of taxon assemblages. The sacred groves were arranged by their size and sequential values. A Whitteker's $\beta$ were calculated for entire assemblage. Similarly it was calculated for tree and shrub separately. The same is shown graphically in figure 5 illustrate with observed species richness in each groves. It was found that there was highest turnover between Karde-Shivnari (0.91) followed by that in Shirkhal-Vanzloli (0.85). The lowest turnover was recorded between pairs of Douli-Sadavali (0.70) and Shivnari-kadivali (0.72).

In case of trees species, it was found that the maximum turnover of species happened between Karde-Shivnari (0.94) followed by Sakhloli-Shirkhal (0.90). The lowest turnover was species between Gavtale-Sakhloli (0.70).

For the shrubs highest turnover of species between Kadivali-Gavtale,Shirkhal-Vanzloli (0.85) followed by Vanzloli-Dhankoli, but lowest turnover in Douli-Sadvali, SakhloliShirkhal $(0.36,0.63)$. Overall, there was no trend in the turnover rate for either the entire assemblage or for trees or shrubs separately (Fig. 8).

Figure.1 Distribution of plant species recorded in this study in various life forms

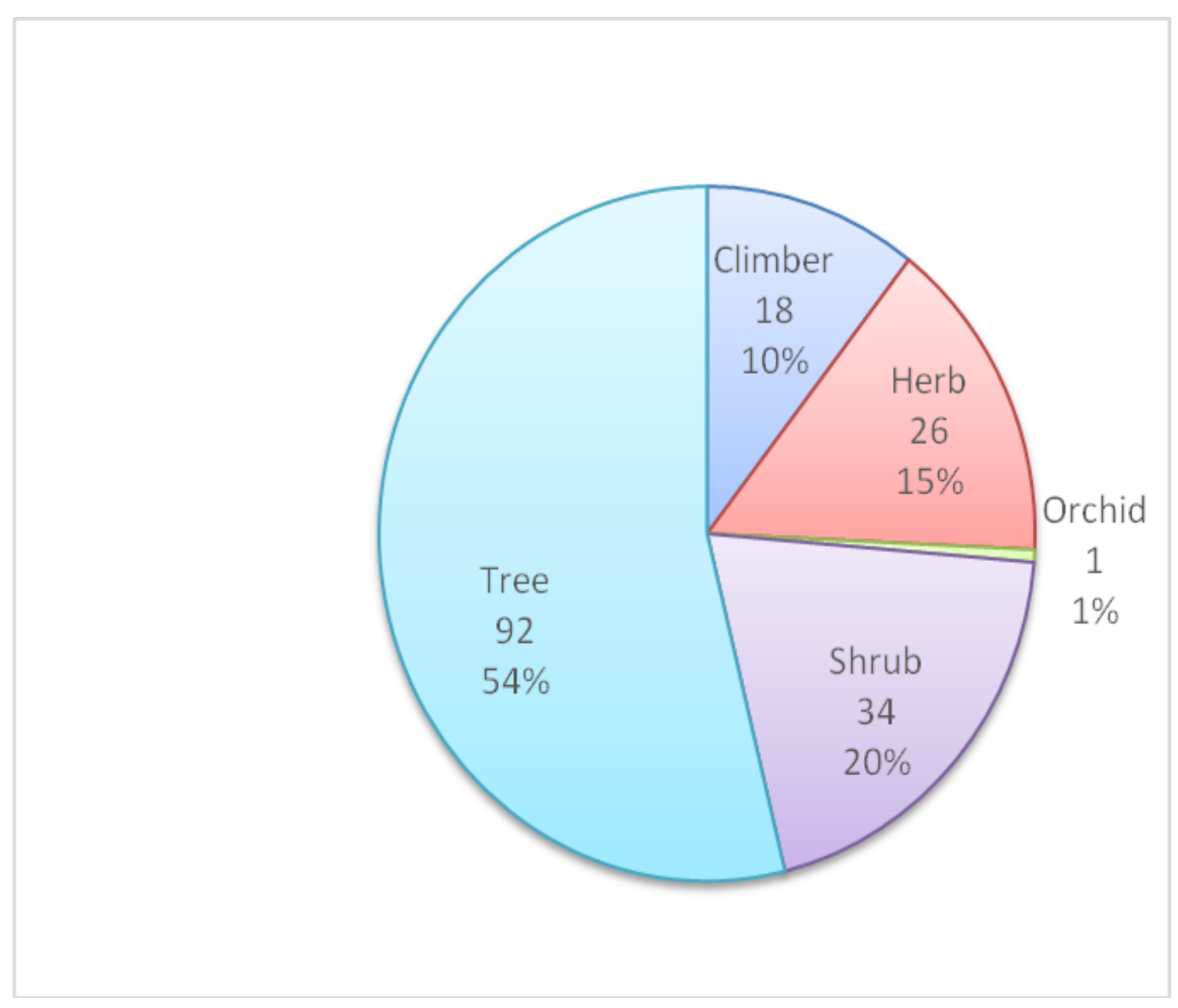


Figure.2 Comparison of observed (diamonds) and estimated Jacknife1 (squares) species richness for different study sites for different life forms
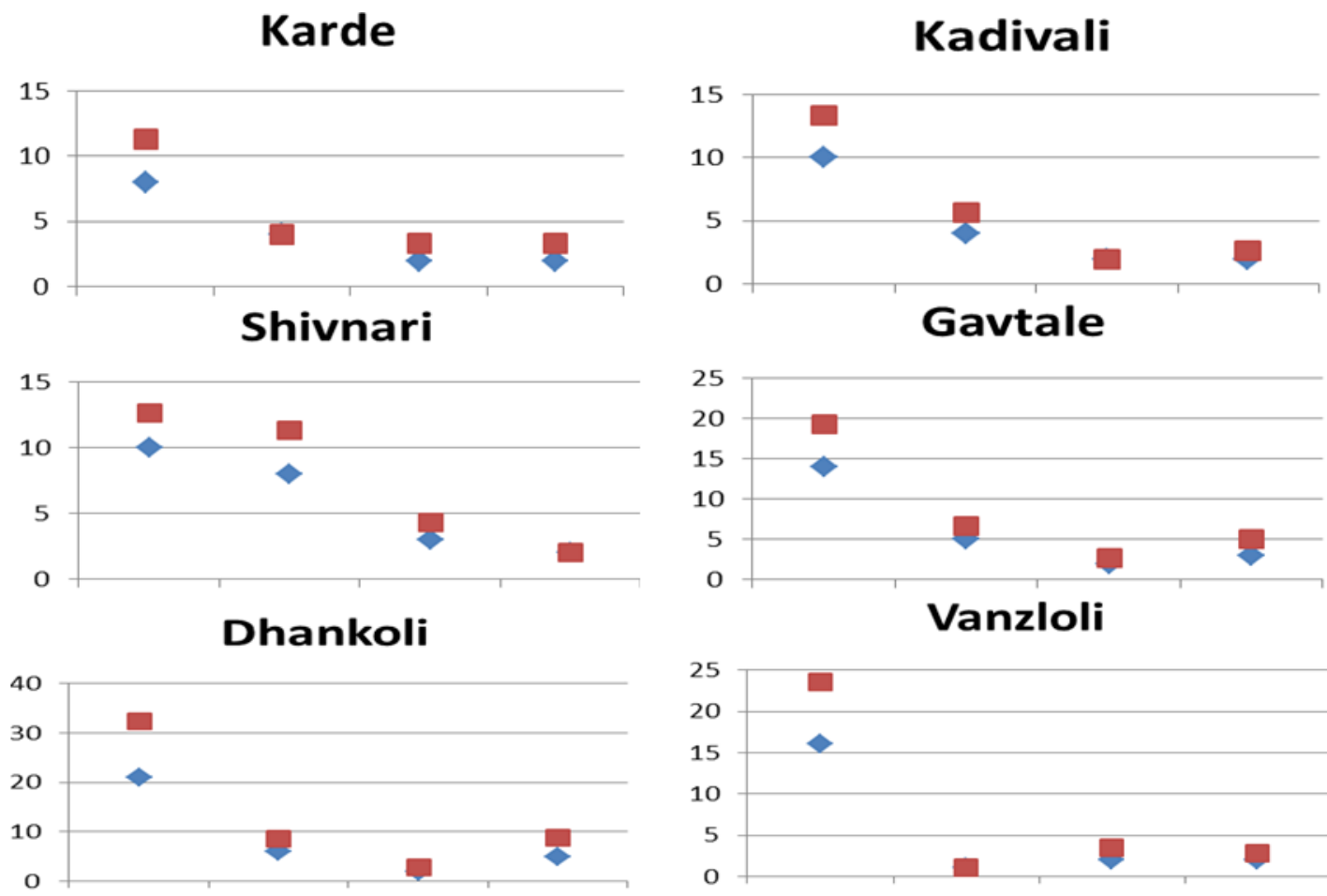

\section{Shirkhal}
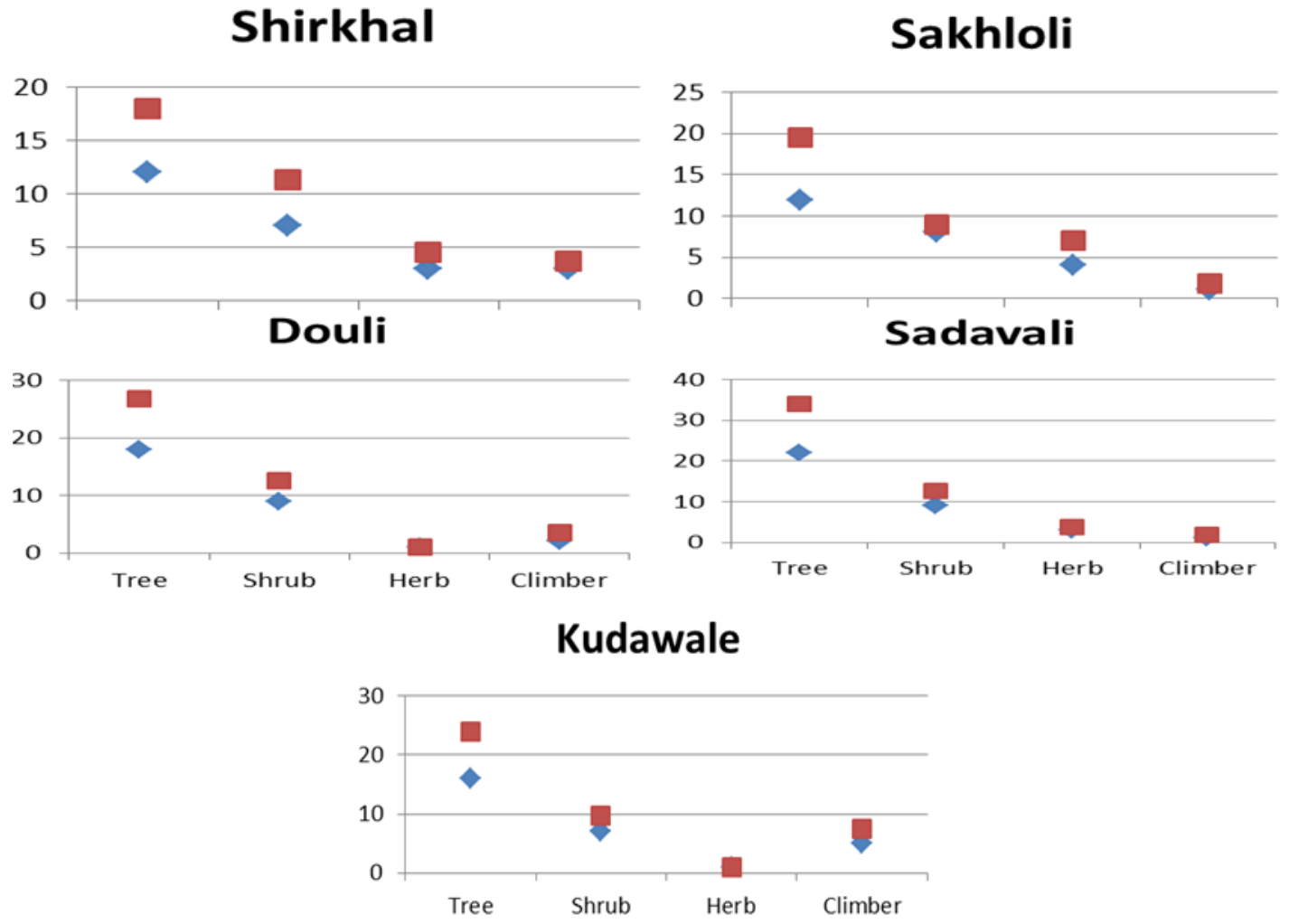
Figure.3 Comparison of observed (diamonds) and estimated Jacknife1 (squares) species richness for in sacred groves and observed species richness (triangles) in vicinity plots

Trees

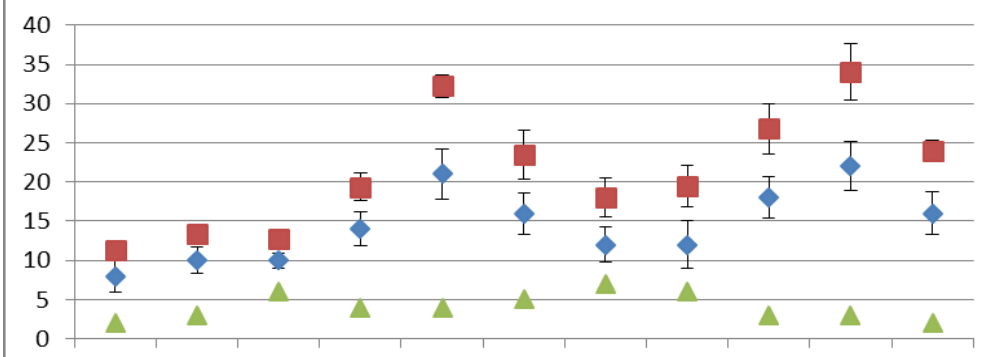

Shrubs

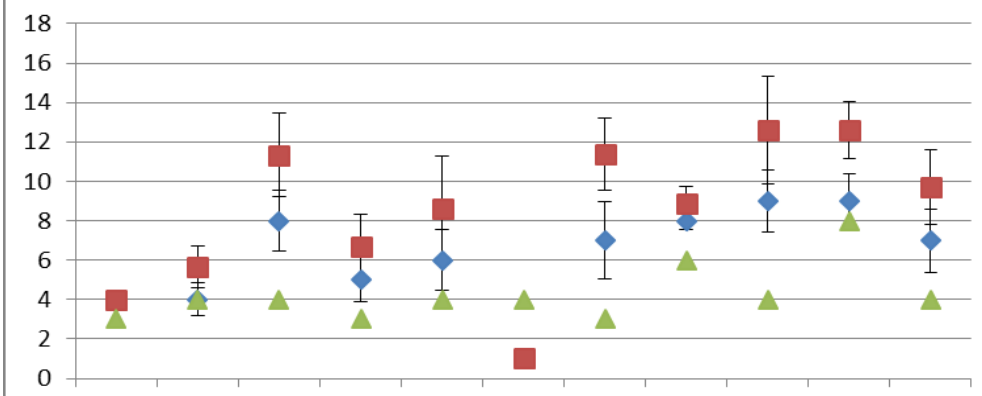

Herbs

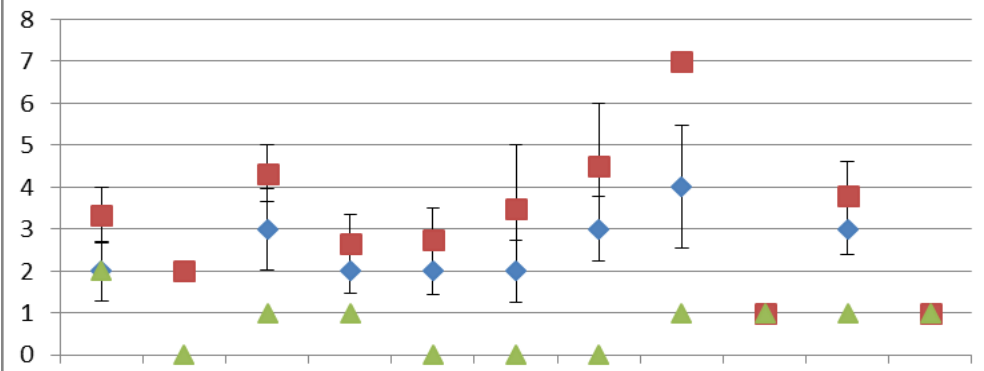

Climbers

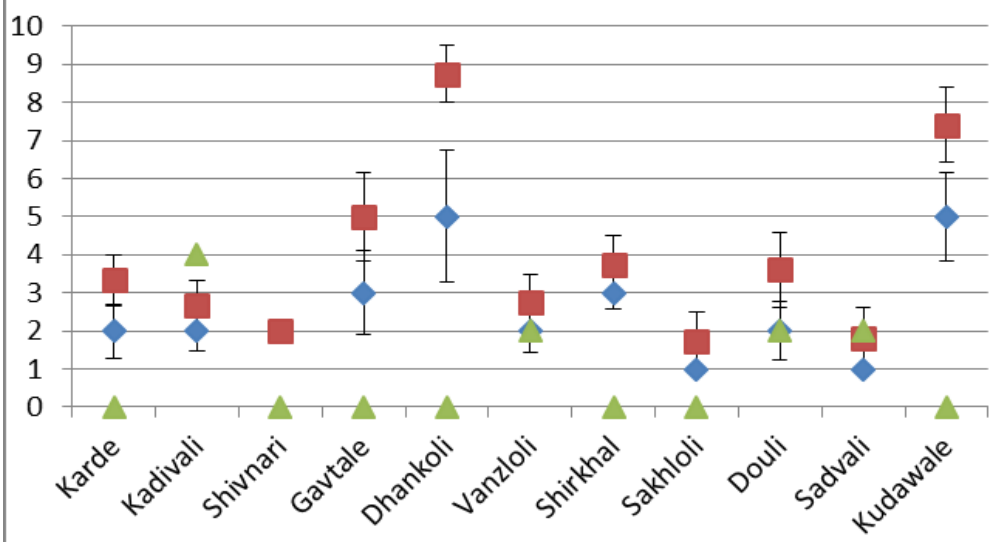


Figure.4 Species accumulation curve of all form with no of quadrant in all sacred groves.

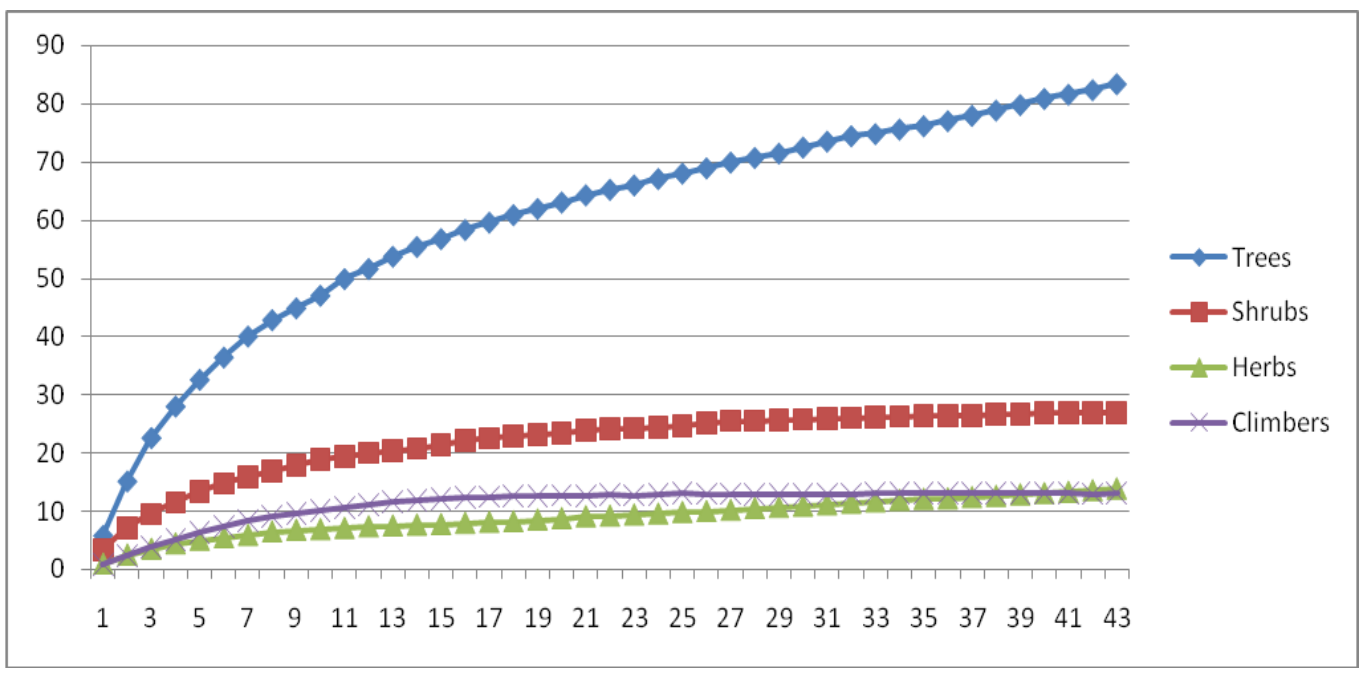

Figure.5 Logistic regression fitted to the species-area relationship of different life-forms across the study sites
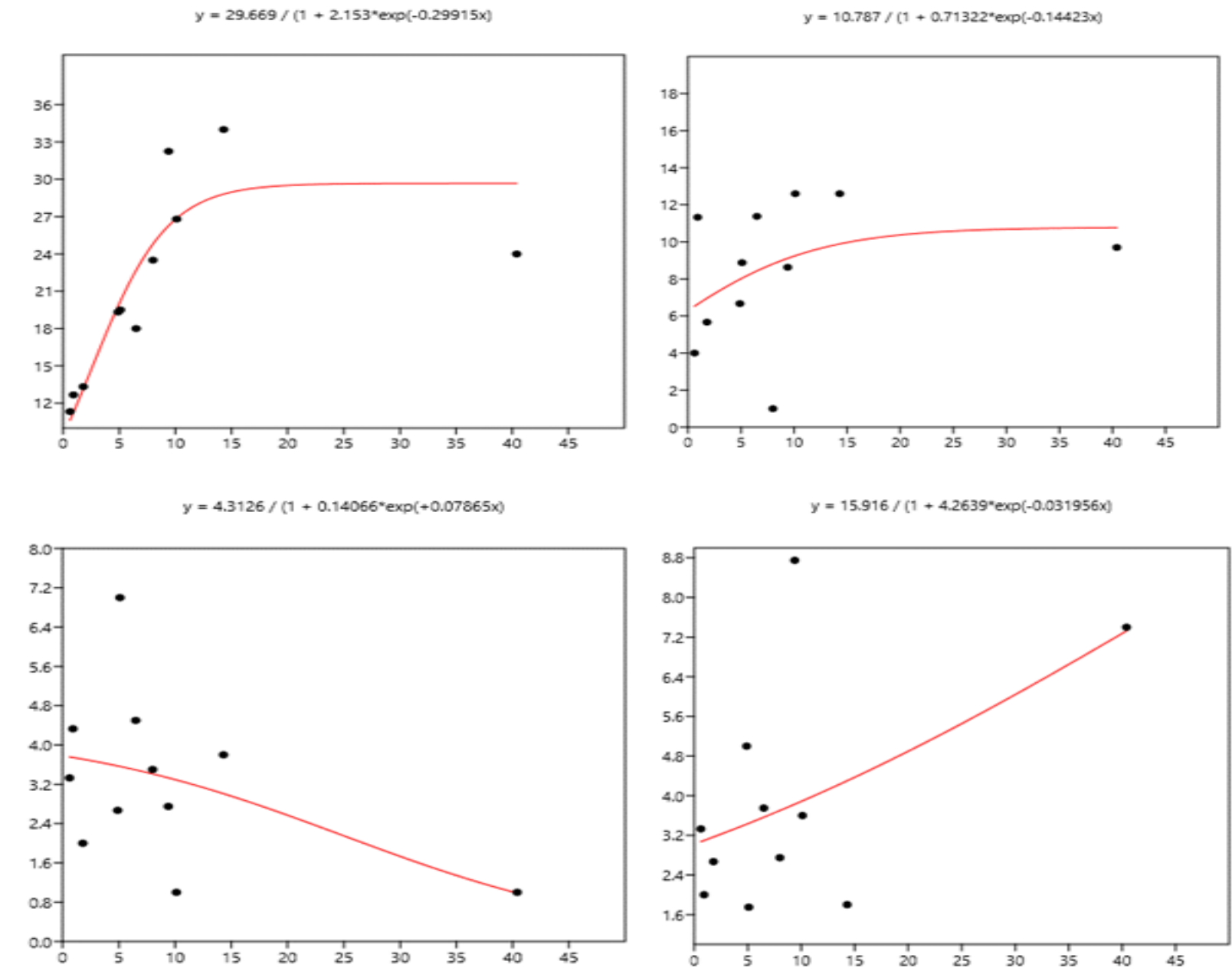
Figure.6 Shannon and Simpson diversity indices based on tree assemblage

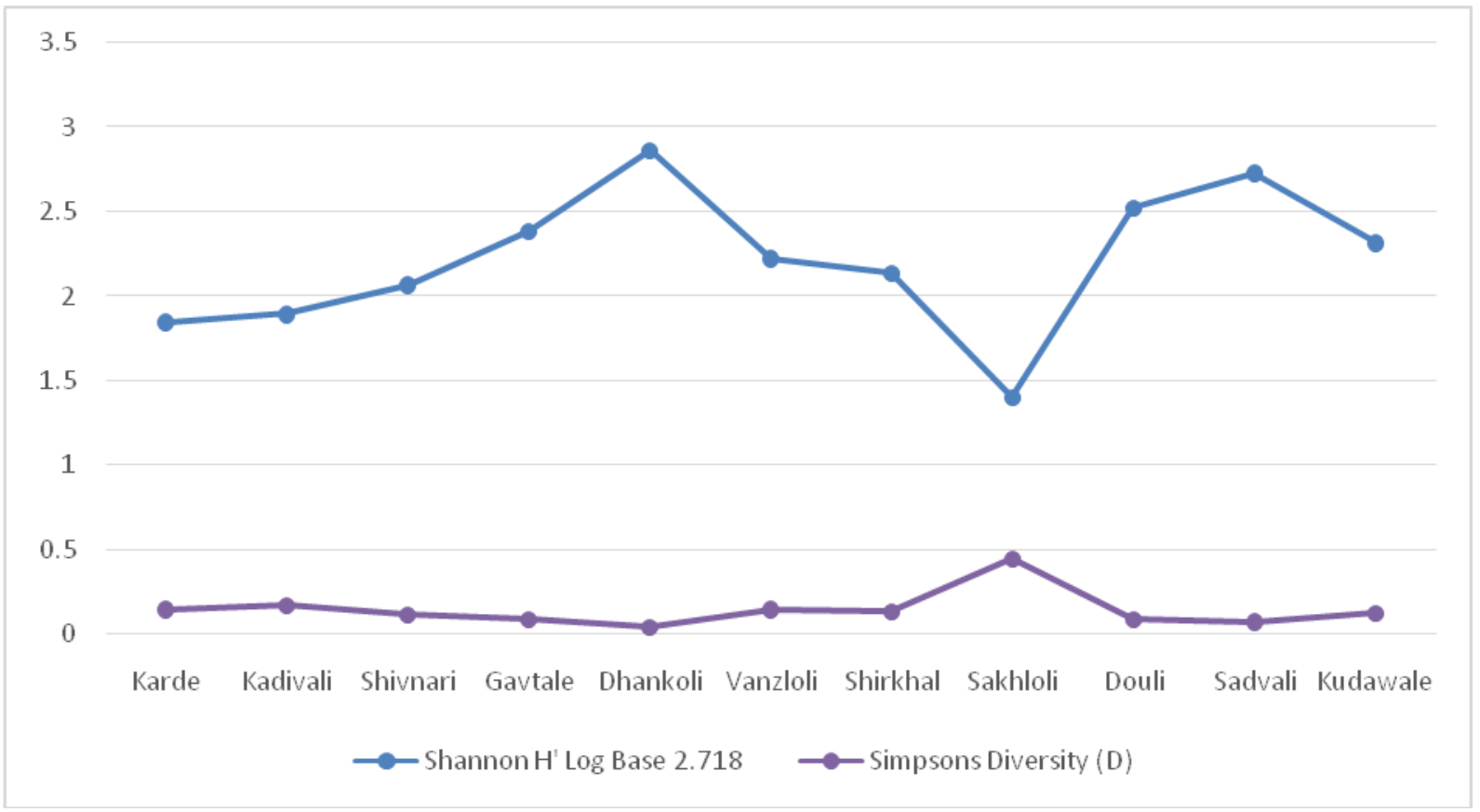

Figure.7 Shannon and Simpson diversity indices based on shrub assemblage

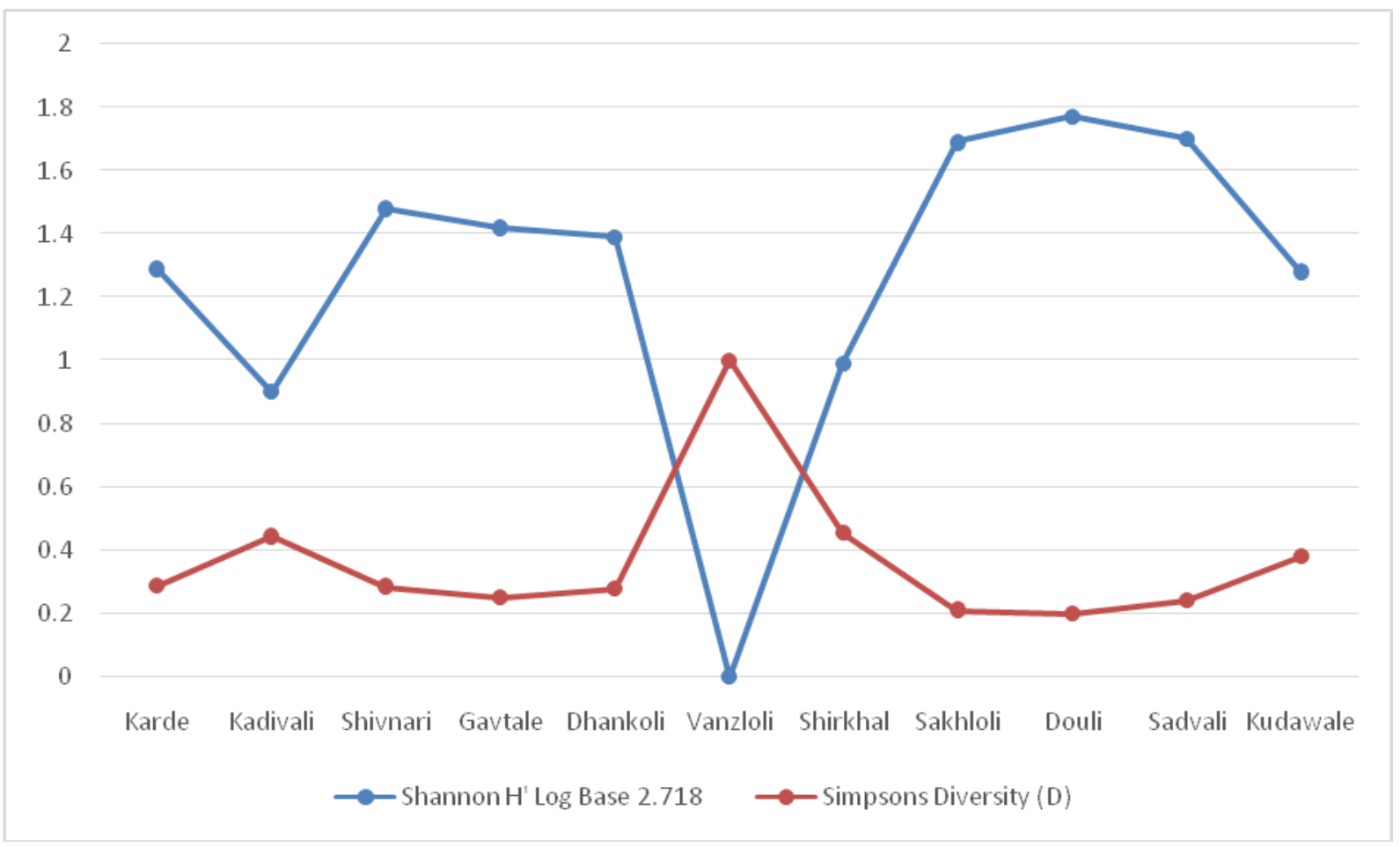


Figure.8 Spatial turnovers of beta diversity a) All Life form species, b) Tree species, c) Shrubs species

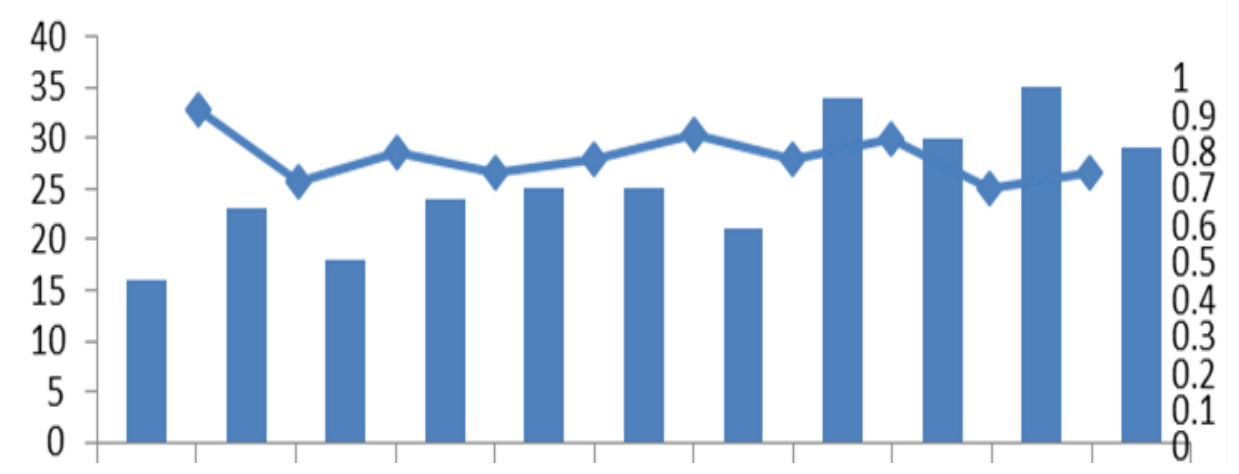

a)

b)
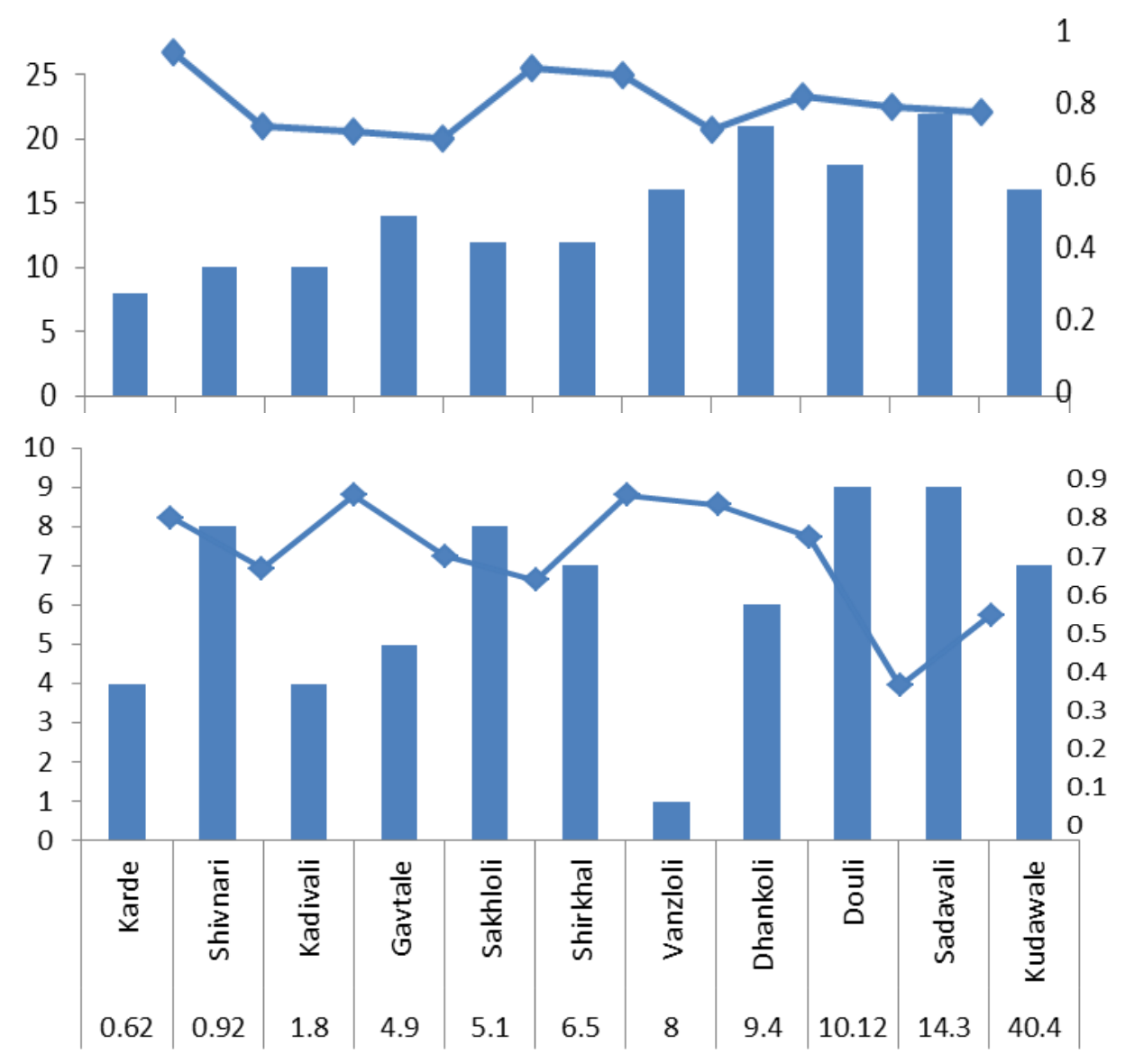
Figure.9 Clustering of sacred groves using Bray-Curtis similarity distance based on their species composition of trees (A) and shrubs (B)

Bray-Curtis Cluster Analysis (Single Link)

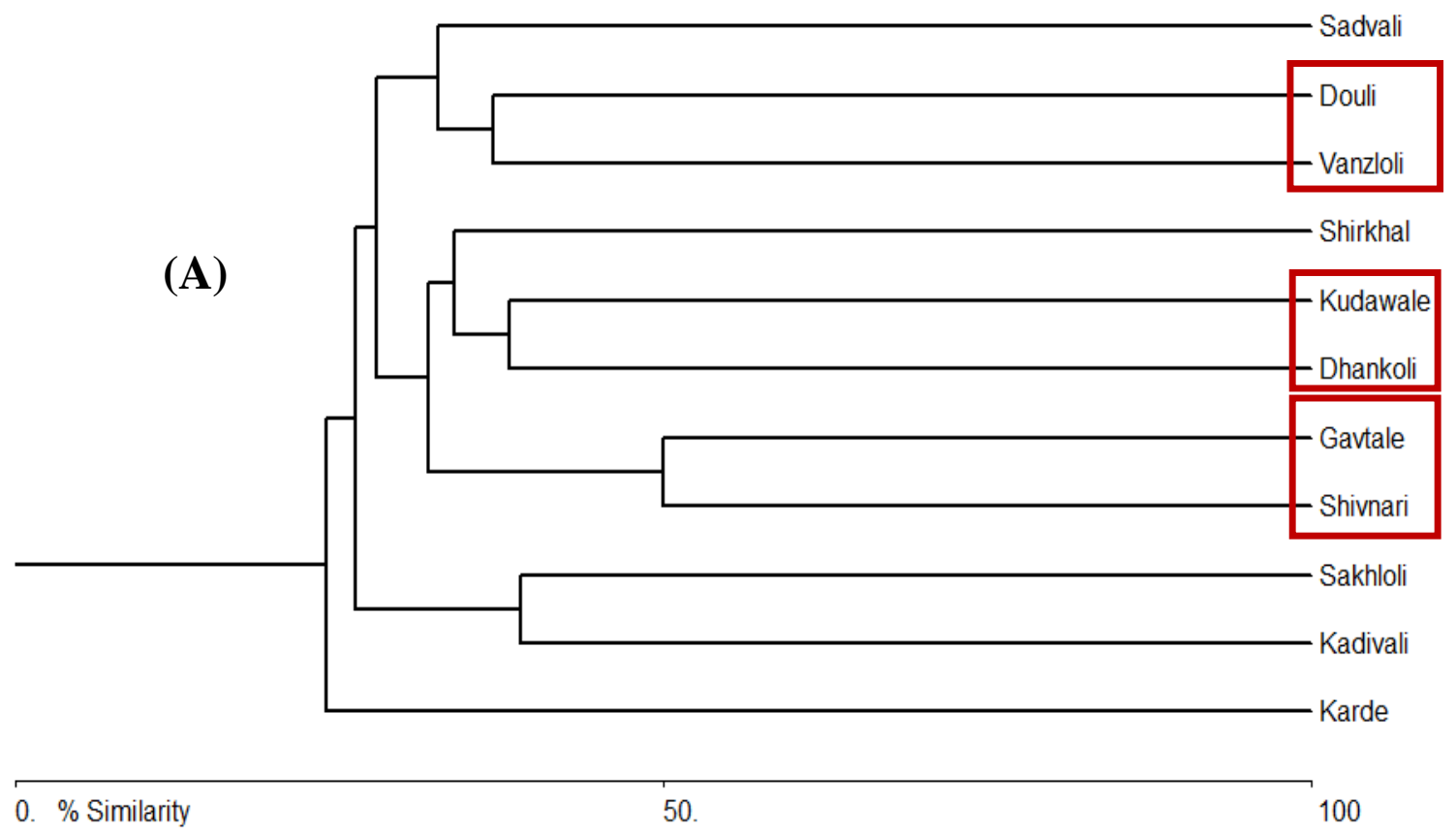

Bray-Curtis Cluster Analysis (Single Link)

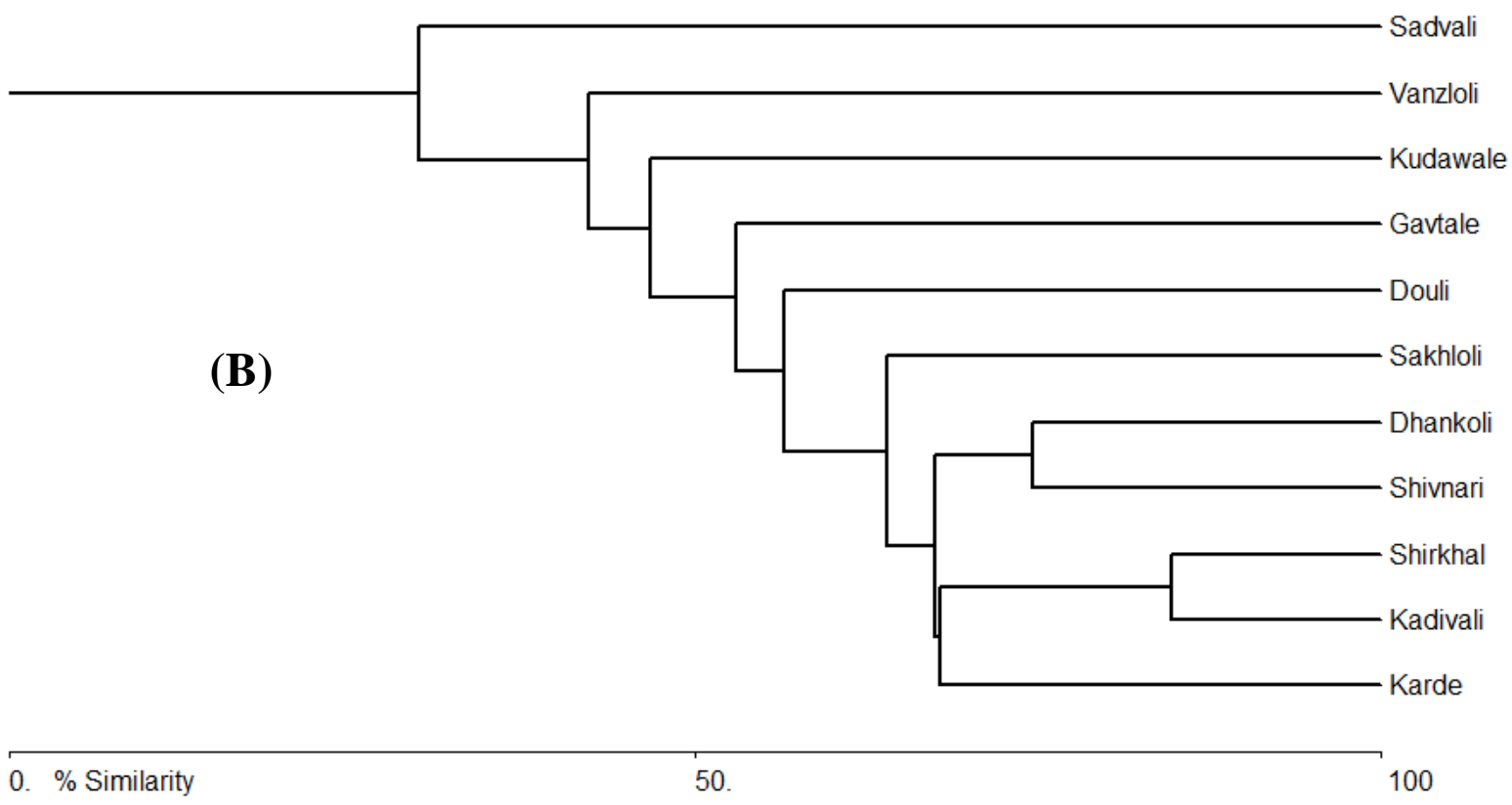


Table.1 Checklist of plants recorded in sacred groves and their vicinity in Dapoli, Maharashtra

\begin{tabular}{|c|c|c|c|c|}
\hline $\begin{array}{l}\text { SI. } \\
\text { No. } \\
\end{array}$ & Scientific name & Family & Common name & Occurrence \\
\hline \multicolumn{5}{|l|}{ Trees } \\
\hline 1 & Acacia auriculiformis & Mimosaceae & $\begin{array}{l}\text { Australian } \\
\text { Babhul }\end{array}$ & Sacred groves \\
\hline 2 & Acacia catechu & Mimosaceae & Khair & Sacred groves \& Vicinity \\
\hline 3 & Acacia mangium & Mimosaceae & Australian teak & Sacred groves \\
\hline 4 & Aegle marmelos & Rutaceae & Bel & Sacred groves \\
\hline 5 & Albizialebbeck & Mimosaceae & Shirish & Sacred groves \\
\hline 6 & Alseodaphnesemicarpifolia & Lauraceae & Phudgus & Sacred groves \\
\hline 7 & Anacardiumoccidentale & Anacardeceae & Kaju & Vicinity \\
\hline 8 & Anodendronpaniculatum & Apocynaceae & Kavali & \begin{tabular}{|l} 
Sacred groves \\
\end{tabular} \\
\hline 9 & Antiaristoxicaria & Moraceae & Chandfal & Sacred groves \\
\hline 10 & Aphanamixispolystachya & Meliaceae & Raktrohida & Sacred groves \\
\hline 11 & Aporosacardiosperma & Phyllantaceae & $\begin{array}{l}\text { Lindley's } \\
\text { Aporosa }\end{array}$ & Sacred groves \\
\hline 12 & Artocarpusheterophyllus & Moraceae & Jackfruit & Sacred groves \\
\hline 13 & Azadirchtaindica & Meliaceae & Neem & Sacred groves \\
\hline 14 & Bauhinia racemosa & Caesalpiniaceae & Apta & Sacred groves \&Vicinity \\
\hline 15 & Bixaorellana & Bixaceae & Shendri & Sacred groves \\
\hline 16 & Bombax ceiba & Bombacaceae & Kate sawar & Sacred groves \& Vicinity \\
\hline 17 & Brideliaretusa & Euphorbiaceae & Asana & Sacred groves \& Vicinity \\
\hline 18 & Butea monosperma & Fabaceae & Palas & Sacred groves \\
\hline 19 & Callicarpa tomentosa & Verbenaceae & Kaarivaati & Sacred groves \\
\hline 20 & Calophylluminophyllum & Clusiaceae & Undi & Sacred groves \\
\hline 21 & Caralliabrachiata & Rhizophoraceae & Phanshi & Sacred groves \\
\hline 22 & Careyaarborea & Lecyhidaceae & Kumbha & Sacred groves \& Vicinity \\
\hline 23 & Caryotaurens & Arecaceae & Bherlimad & Sacred groves \\
\hline 24 & Casuarina equisetifolia & Casuarinaceae & Suru & Sacred groves \\
\hline 25 & Catunaregamspinosa & Rubiaceae & Madanphal & Sacred groves \\
\hline 26 & Chukrasiatabularis & Meliaceae & Chukrasia & Sacred groves \\
\hline 27 & Dilleniaindica & Dilleniaceae & Karmal & Sacred groves \\
\hline 28 & Dimorphocalyxglabellus & Euphorbiaceae & Jodpakli & Sacred groves \\
\hline 29 & Diospyros montana & Ebenaceae & Lohari & Sacred groves \\
\hline 30 & Erinocarpusnimmonii & Tiliaceae & Cher & Sacred groves \\
\hline 31 & Erythrina variegata & Fabaceae & Pangara & Sacred groves \& Vicinity \\
\hline 32 & Ficusbenghalensis & Moraceae & Vad & Sacred groves \\
\hline 33 & Ficushispida & Moraceae & Kala umbar & Sacred groves \\
\hline 34 & Ficusracemosa & Moraceae & Umber & Sacred groves \\
\hline
\end{tabular}




\begin{tabular}{|c|c|c|c|c|}
\hline 35 & Ficusreligiosa & Moraceae & Pimpal & Sacred groves \\
\hline 36 & Ficustinctoria & Moraceae & Datir & Sacred groves \\
\hline 37 & Ficusvirens & Moraceae & Basari & Sacred groves \\
\hline 38 & Firmianacolorata & Sterculiaceae & Koushi & Sacred groves \\
\hline 39 & Flacourtiamontana & Flacourtiaceae & Ataki & Sacred groves \\
\hline 40 & Garcinia indica & Clusiaceae & Kokam & Sacred groves \\
\hline 41 & Garugapinnata & Burseraceae & Kakad & Sacred groves \\
\hline 42 & Glochidionellipticum & Phyllanthaceae & Bhoma & Sacred groves \\
\hline 43 & Gmelina arborea & Verbenaceae & Shivan & Sacred groves \& Vicinity \\
\hline 44 & Grewiaserrulata & Tiliaceae & Kawri & Sacred groves \\
\hline 45 & Grewiatilifolia & Tiliaceae & Dhaman & \begin{tabular}{|l|} 
Sacred groves \\
\end{tabular} \\
\hline 46 & Haldinacordifolia & Rubiaceae & Haladu & Sacred groves \\
\hline 47 & $\begin{array}{l}\text { Heterophragmaquadrilocul } \\
\text { are }\end{array}$ & Bignoniaceae & Varas & Sacred groves \\
\hline 48 & Holarrhenapubescens & Apocynaceae & Kuda & Sacred groves \\
\hline 49 & Holigarnagrahamii & Anacardiaceae & Biboi & Sacred groves \\
\hline 50 & Holopteleaintegrifolia & Urticaceae & Wavala & Sacred groves \\
\hline 51 & Hydnocarpuspentandrus & Flacourtiaceae & Kadu kawath & Sacred groves \\
\hline 52 & Ixora brachiata & Rubiaceae & Lokhandi & Sacred groves \\
\hline 53 & Lagerstroemia microcarpa & Lythraceae & Nana & Sacred groves \\
\hline 54 & Lagerstroemia speciosa & Lythraceae & Tamhan & Sacred groves \\
\hline 55 & Leucaena leucocephala & Mimosaceae & Subabhul & Sacred groves \\
\hline 56 & Macaranga peltata & Euphorbiaceae & Chandvad & Sacred groves \\
\hline 57 & Mallotusphilippensis & Euphorbiaceae & Kunkufal & Sacred groves \\
\hline 58 & Mammeasuriga & Clusiaceae & Surangi & Sacred groves \\
\hline 59 & Mangiferaindica & Anacardiaceae & Mango & Sacred groves \& Vicinity \\
\hline 60 & Memecylonumbellatum & Melastomataceae & Anjan & Sacred groves \& Vicinity \\
\hline 61 & Microcospaniculata & Tiliaceae & Shirali & Sacred groves \\
\hline 62 & Mimusopselengi & Sapotaceae & Bakul & Sacred groves \\
\hline 63 & Morindatinctoria & Rubiaceae & Bartondi & Vicinity \\
\hline 64 & Murrayapaniculata & Rutaceae & Kamini & Sacred groves \\
\hline 65 & Neolamarckiacadamba & Rubiaceae & Kadamb & Sacred groves \\
\hline 66 & Nothapodytesnimmoniana & Icacinaceae & Narkya & Sacred groves \\
\hline 67 & Oroxylumindicum & Bignoniaceae & Tetoo & Sacred groves \\
\hline 68 & Peltophorumpterocarpum & Caesalpiniaceae & Piwalagulmohar & Sacred groves \\
\hline 69 & Perceamacarantha & Lauraceae & Gulaamba & Sacred groves \\
\hline 70 & Phyllanthus emblica & Phyllanthaceae & Amala & Sacred groves \\
\hline 71 & Plumeria rubra & Apocynaceae & Pandharachafa & Sacred groves \\
\hline 72 & Pongamiapinnata & Fabaceae & Karanj & Sacred groves \\
\hline 73 & Sageraealaurifolia & Annonaceae & Harkinjal & Sacred groves \\
\hline 74 & Saracaasoca & Caesalpiniaceae & Seetaashok & Sacred groves \\
\hline
\end{tabular}




\begin{tabular}{|c|c|c|c|c|}
\hline 75 & Semecarpusanacardium & Anacardiaceae & Bibba & Vicinity \\
\hline 76 & Sterculiaguttata & Sterculiaceae & Kukar & Sacred groves \\
\hline 77 & Sterculiaurens & Sterculiaceae & Kandol & Sacred groves \\
\hline 78 & Stereospermumcolais & Bignoniaceae & Padal & Sacred groves \\
\hline 79 & syzygiumcumini & Myrtaceae & Jambhul & Sacred groves \& Vicinity \\
\hline 80 & Tabernamontanaheyneana & Apocynaceae & Nag kuda & Sacred groves \\
\hline 81 & Tectonagrandis & Verbenaceae & Saag & Vicinity \\
\hline 82 & Terminalia bellirica & Combretaceae & Behada & Sacred groves \& Vicinity \\
\hline 83 & Terminalia chebula & Combretaceae & Harda & Vicinity \\
\hline 84 & Terminalia cuneata & Combretaceae & Arjun & Sacred groves \\
\hline 85 & Terminalia elliptica & Combretaceae & Ain & Sacred groves \& Vicinity \\
\hline 86 & Terminalia paniculata & Combretaceae & Kinjal & Sacred groves \& Vicinity \\
\hline 87 & Tremaorientalis & Cannabaceae & Ghol & Sacred groves \\
\hline 88 & Vitex altissima & Verbenaceae & Balage & Sacred groves \\
\hline 89 & Xantolistomentosa & Sapotaceae & Kumbal & Sacred groves \\
\hline 90 & Xyliaxylocarpa & Mimosaceae & Yerul & Sacred groves \\
\hline 91 & Zanthoxylumrhetsa & Rutaceae & Tisal & Sacred groves \& Vicinity \\
\hline 92 & Ziziphusjujuba & Rhamnaceae & Bor & Sacred groves \\
\hline \multicolumn{5}{|c|}{ Shrubs } \\
\hline 93 & Abelmoschus ficulneus & Malvaceae & Ran bhendi & Sacred groves \\
\hline 94 & Atalantiamonophylla & Rutaceae & Makadlimbu & Sacred groves \\
\hline 95 & Barleriacristata & Acanthaceae & Koranti & Sacred groves \\
\hline 96 & Barleriaprattensis & Acanthaceae & Gulabikoranti & Sacred groves \\
\hline 97 & Breyniaretusa & Phyllanthaceae & Dalfodi & Sacred groves \& Vicinity \\
\hline 98 & Butea superba & Fabeaceae & Lata palas & Sacred groves \\
\hline 99 & Carissa congesta & Apocynaceae & Karvand & Sacred groves \& Vicinity \\
\hline 100 & Clerodendrumserratum & Verbenaceae & Bharangi & Sacred groves \& Vicinity \\
\hline 101 & Costusspeciosus & Zingiberaceae & Pev & Sacred groves \& Vicinity \\
\hline 102 & Decaschistiatrilobata & Malvaceae & Mysore mallow & Sacred groves \\
\hline 103 & Derris scandens & Fabaceae & Garudvel & Sacred groves \\
\hline 104 & Embeliatsjeriam-cottam & Primulaceae & Ambati,Wavding & Sacred groves \\
\hline 105 & Eugenia phillyraeoides & Myrtaceae & Ran jambhul & Sacred groves \\
\hline 106 & Euphorbia neriifolia & Euphorbiaceae & Neya-dungra & Sacred groves \\
\hline 107 & Gardenia gummifera & Rubiaceae & Dikemali & Sacred groves \\
\hline 108 & Helicteresisora & Sterculiaceae & Murud sheng & Sacred groves \\
\hline 109 & Hemidesmus indicus & Apocynaceae & Anantmul & Sacred groves \\
\hline 110 & Hygrophilaauriculata & Acanthaceae & Talimkhana & Sacred groves \\
\hline 111 & Ixora coccinea & Rubiaceae & Devhara & Sacred groves \\
\hline 112 & Justicia adhatoda & Acanthaceae & Adulasa & Sacred groves \\
\hline 113 & Lantana camara & Verbenaceae & Ghaneri & Vicinity \\
\hline
\end{tabular}




\begin{tabular}{|c|c|c|c|c|}
\hline 114 & Leeaindica & Vitaceae & Dinda & Sacred groves \& Vicinity \\
\hline 115 & Meynalaxiflora & Rubiaceae & Alu & Sacred groves \& Vicinity \\
\hline 116 & Plumbago indica & Plumbaginaceae & Lal chitrak & Sacred groves \\
\hline 117 & Plumbago zeylanica & Plumbaginaceae & Chitrak & Sacred groves \\
\hline 118 & Rotula aquatica & Boraginaceae & Machim & Sacred groves \\
\hline 119 & Senna tora & Caesalpiniaceae & Takala & Vicinity \\
\hline 120 & Solanum anguivi & Solanaceae & Amb-keli & Sacred groves \\
\hline 121 & Thespesia lampas & Malvaceae & Ran bhendi & Sacred groves \& Vicinity \\
\hline 122 & Triumfettarhomboidea & Tiliaceae & Jhinjhardi & Sacred groves \\
\hline 123 & Vitex negundo & Verbenaceae & Nirgudi & Sacred groves \& Vicinity \\
\hline 124 & Woodfordiafruticosa & Lythraceae & Dhayati & Vicinity \\
\hline 125 & Ziziphusoenoplia & Rhamnaceae & Burgi & Sacred groves \& Vicinity \\
\hline 126 & Ziziphus rugosa & Rhamnaceae & Toran & Sacred groves \& Vicinity \\
\hline \multicolumn{5}{|c|}{ Climbers } \\
\hline 127 & AbrusPrecatorius & Fabaceae & Gunj & Vicinity \\
\hline 128 & Asparagus racemosus & Asparagaceae & Shatavari & Sacred groves \\
\hline 129 & Cycleapeltata & Menispermaceae & Thoralipadwal & Sacred groves \& Vicinity \\
\hline 130 & Dalbergiahorrida & Fabaceae & Pendgul & Sacred groves \\
\hline 131 & Dregeavolubilis & Asclepiadaceae & Harandodi & Sacred groves \\
\hline 132 & Embeliaribes & Primulaceae & Wavding & Sacred groves \\
\hline 133 & Entadarheedei & Mimosaceae & Garambi & Sacred groves \\
\hline 134 & Getonia floribunda & Combretaceae & Ukshi & Sacred groves \& Vicinity \\
\hline 135 & Gloriosa superba & Liliaceae & Kallavi & Sacred groves \\
\hline 136 & Gnetumedule & Gnetaceae & Umbali & Sacred groves \\
\hline 137 & Ipomoea campanulata & Convolvulaceae & Tamber vel & Sacred groves \& Vicinity \\
\hline 138 & Jasminum malabericum & Oleaceae & Jasminum & Sacred groves \\
\hline 139 & Moullavaspicata & Caesalpiniaceae & Waghati & Sacred groves \\
\hline 140 & Mucunamonosperma & Fabaceae & Pandharikhajkuiri & Sacred groves \\
\hline 141 & Mucunapruriens & Fabaceae & Khajkhujali & Sacred groves \& Vicinity \\
\hline 142 & Piper longum & Piperaceae & Pimpali & Sacred groves \\
\hline 143 & Smilax ovalifolia & Smilacaceae & Ghotvel & Sacred groves \& Vicinity \\
\hline 144 & Tinosporacordifolia & Menispermaceae & Gulvel & Sacred groves \\
\hline \multicolumn{5}{|c|}{ Herbs } \\
\hline 145 & Adenoonindicum & Asteraceae & Sonaki & Sacred groves \\
\hline 146 & $\begin{array}{l}\text { Amorphophalluscommutatu } \\
\mathrm{s}\end{array}$ & Araceae & Mogarikand & Sacred groves \\
\hline 147 & Begonia concanensis & Begoniaceae & Gajkarnika & Sacred groves \\
\hline 148 & Biophytumsensitivum & Oxalidaceae & Jhajera & Sacred groves \& Vicinity \\
\hline 149 & Celosia argentea & Amaranthaceae & Kurdu & Sacred groves \& Vicinity \\
\hline 150 & Ceryptocorynecognata & Araceae & Water trumpet & Sacred groves \\
\hline
\end{tabular}




\begin{tabular}{|r|l|l|l|l|}
\hline 151 & Canscoradiffusa & Gentianaceae & Kilvar & Sacred groves \& Vicinity \\
\hline 152 & Crotalaria filipes & Fabaceae & Phatphati & Sacred groves \\
\hline 153 & Curcuma amada & Zingiberaceae & Ranhalad & Sacred groves \\
\hline 154 & Curcuma pseudomontana & Zingiberaceae & Ran halad & Sacred groves \& Vicinity \\
\hline 155 & Cyathoclinepurpurea & Asteraceae & Gangotra & Sacred groves \\
\hline & Cynarospermumasperrimu & & & \\
156 & $m$ & Acanthaceae & Dikana & Sacred groves \& Vicinity \\
\hline 157 & Desmodiumgangeticum & Fabaceae & Salvan & Sacred groves \\
\hline 158 & Ensetesuperbum & Musaceae & Ran Kel / Chavai & Sacred groves \\
\hline 159 & Eranthemumroseum & Acanthaceae & Ranaboli & Sacred groves \\
\hline 160 & Eriocauloneurypeplon & Eriocaulaceae & Gend & Sacred groves \\
\hline 161 & Haplanthodestentaculatus & Acanthaceae & Nilajakara & Sacred groves \\
\hline 162 & Haplanthodesverticillatus & Acanthaceae & Jhankara & Sacred groves \\
\hline 163 & Hemigraphislatebrosa & Acanthaceae & Morpankhi & Sacred groves \\
\hline 164 & Hygrophilaserpyllum & Acanthaceae & Ran tevan & Sacred groves \\
\hline 165 & Impatiens minor & Balsaminaceae & Terada & Sacred groves \\
\hline 166 & Pentanemaindicum & Asteraceae & Sonkadi & Sacred groves \\
\hline 167 & Phyllocephalumscabridum & Asteraceae & Parnagumphi & Sacred groves \\
\hline 168 & Pogostemondeccanensis & Lamiaceae & JambhliManjiri & Sacred groves \\
\hline 169 & Polygonum glabrum & polygonaceae & Marsh buckwheat & Sacred groves \\
\hline 170 & Smithiasalsuginea & Fabaceae & Brackish Smithia & Sacred groves \\
\hline 171 & Aeridesringens & Orchidaceae & Ringaniriamri & Sacred groves \& Vicinity \\
\hline
\end{tabular}

\section{Cluster analysis}

Sacred groves were clustered on the basis of tree species composition using Bray-Curtis distance in programme Biodiversity Pro (McAleece et al., 1997). It can be seen that the pairs of sacred groves similar in tree composition are also the pairs without much inter-patch distance. For example, Gavtale and Shivnari are separated by the smallest distance $(1.78 \mathrm{~km})$, Kudawale and Dhankoli $(2.10 \mathrm{~km})$, Douli and Vanzloli (3.57). This comes into perspective when it is noted that the maximum inter-patch distance is $28.02 \mathrm{~km}$ (Gavtale and Vanzloli). However, it must also be noted that Sakhloli and Kadivali which are relatively far apart also grouped together. A look at the raw data reveals that presence of Terminalia bellirica in relatively large numbers in these two sacred groves was a reason behind clustering them together.
On the other hand, clustering based on shrub species composition revealed no such groupings which could be correlated with the physical distance between the sacred grove. This goes on to show that while trees give peculiarity to sacred groves, shrubs are well distributed throughout the study area and cannot be used for making distinctions between sacred groves.

From both the clustering, however, it seems that Karde has a very distinct species composition which is true and owes its distinctness, perhaps, to its closeness to the coast. In Boyina et al., (2011), the clustering of sacred groves and reference forest stands was attempted and it was found that the sacred groves except one clustered together. Ambinakudige and Sathish (2008) in their study of species evenness measurements indicated that all the three habitats differing in 
land tenures had similar evenness. Redeemed and unredeemed coffee plots were similar in species richness abundance but were different compared to sacred groves (Fig. 9).

\section{Rare and endemic plants}

In present study we recorded total 10 rare and threatened plants and 29 endemic plants from the 11 sacred groves of Dapoli taluka (Table 1). The status of plant species as per IUCN Red List is also provided (www.iucnredlist.org). From the observations it is clear that sacred groves of Dapoli hold rich biodiversity of rare, threatened and endemic plant species. Sacred groves of Dapoli Taluka have been reported to hold important and rare floristic elements like Entada scandens, Antiaristoxicaria, Saracaasoca (locally rare) and also threatened species like Cryptocoryne cognate (Ghalme 2013, Patil 2016). Ghalame (2013)carried out an inventory for ethno-medico-botanical explorations in sacred groves of Dapoli tehsil. During his inventory he recorded 281 plant species of which there were 19 threatened and 36 endemic plant species.

\section{References}

Ambinakudige, S. and Satish, B. N. 2008. Comparing tree diversity and composition in Coffee farm and sacred forest in the Western Ghat of India. Biodivers conserve, Pp. 1-14.

Boyina, R., P.K. R., Babu M.V., S., Reddy, M. S., Reddy, A., M., Y., V., Rao, Sunitha, S. and Ganeshaiah S, K.N. 2011. Sacred groves in southern eastern ghats, India: Are they better managed than forest reserves? Tropical Ecology, 52(1): 79-90.

Chandrashekara, U., M. and Sankar, S.1998. Ecology and management of sacred groves in Kerala, India. Forest Ecology and Management, 112: 165-177.
Colwell, R.K.1997. EstimateS: statistical estimation of species richness and shared species from samples. Version 8.

Gadgil, M. and Vartak, V. D. 1975. Sacred groves of India-A plea for continued conservation. Journal of the Bombay Natural History Society, 72(2), 313320.

Gadgil, M. and Vartak, V. D. 1976. The sacred groves of Western Ghats in India. Economic Botany, 30, 152-160.

Ghalame, R. L. 2013. Ethno-MedicoBotanical studies on some sacred grove of Dapoli tehsil, district Ratnagiri, M.S. (Ph.D. thesis).

IUCN (2015). International Union for conservation Nature. www.iucnredlist. org.

Heltshe, J. and Forrester, N. E. 1983. Estimating species richness using the jackknife procedure. Biometrics, 39:1.

Magurran, A.E. 2004. Measuring biological diversity. Blackwell Publishing Science, Oxford.

McAleece N, Gage J D, Lambshead J, Patterson G L J (1997) Biodiversity Professional. The Natural History Museum \& The Scottish Association for Marine Science.

Page, N.V., Qureshi Q, Rawat G. S. and Kushalappa C.G. 2009. Plant diversity IN sacred forest fragments of Western Ghats: a comparative study of life forms. Plant Ecol (2010) 206: 237-50.

Patil, V.K.2016. Diversity of Spider Assemblages in Sacred Groves of Ratnagiri, Maharashtra: Implications for Conservation Management in the Landscape (Ph.D. thesis).

Ray, R., and Ramachandra, T. V. 2010. Small sacred groves in local landscape: are they really worthy for conservation? Current Science, 98(9), 1178-1180.

Ulrich, W.2006. Nestedness - a FORTRAN program for calculating ecological matrix temperature. 
Wilson, M and Shmida, A. (1984). Measuring data. J Ecol., 72:1055-1064. beta diversity with presence-absence

\section{How to cite this article:}

Gawade, S.G., V.K. Patil, Y.B. Patil, S.M. Sangare, V.D. Maihske, A.D. Rane and Narkhede, S.S. 2018. Plant Diversity in Sacred Groves of Dapoli: A Comparative Study of Four Life Forms. Int.J.Curr.Microbiol.App.Sci. 7(12): 2502-2520.

doi: https://doi.org/10.20546/ijcmas.2018.712.285 